\title{
CRACOW CITY GAMES - AN INNOVATION IN TOURISM?
}

\author{
W. Warcholik \\ Uniwersytet Pedagogiczny w Krakowie, Instytut Geografii, \\ Zakład Turystyki i Badań Regionalnych \\ ul. Podchorażych 2, 30-084 Kraków \\ e-mail:warwitek@gmail.com
}

\begin{abstract}
Cities have always been the most popular tourist destination. In fact, as per G. J. Ashworth $(2000,2009)$, tourism is more associated with cities than any other areas, and it is stronger related to anthropogenic elements than to natural resources. Cracow, among many others, is an example of a city, where within the administrative area, one can find places that are not typically urban.
\end{abstract}

Key words: urban game, tourism, guide, city sightseeing

Cities have always been the most popular tourist destination. In fact, as per G. J. Ashworth $(2000,2009)$, tourism is more associated with cities than any other areas, and it is stronger related to anthropogenic elements than to natural resources. Cracow, among many others, is an example of a city, where within the administrative area, one can find places that are not typically urban. City games are held not only in municipal districts, but also in non-urban environmental and agricultural spaces, which are considered to be parts of the city's infrastructure. The non-urban kind of attributes present in the area used to be considered the only factor making a city appealing, with tourists attractions being only an added value. Currently it is acknowledged, that tourist traffic organization and maintenance, especially tourist services and promotion, are vital elements determining the city's attractiveness. A. Spack (1975), G. Wall and J. Sinnott (1980), A. Lew (1991), C. Corkery and A. Bailey (1994), H. Hughes (2003) and many others elaborated on urban touristic values and their reflection in the city's promotional materials and campaign.

A city game is a type of an entertainment organized in real time, where a selected urban area is the game board on which players find their solutions to tasks outlined in the game scenario. The win is determined either by the time needed for completion or the number and the significance of tasks completed. Certain aspects of a typical role playing game are also present in a city game. For instance, participants impersonate fictional characters, the game is played in a fictional setting and according to rules described in the game scenario (also called the game mechanics). Additionally, a city game liaises other forms, such as street happenings, paper chases, treasure hunts, computer games, or even flash mobs, i.e. spontaneous initiatives assembling people in a public place to perform a short, unusual act. According to R. Więckowski (1979), an activity can only be called a game when it is entertaining and pleasurable, develops along certain rules, includes a reward and is always finalized by a win or a defeat.

An important aspect of planning a city game scenario is a range of tourist attractions available on the game board. A tourist attraction is defined as a collection of environmental

(C) Warcholik W., 2013 
and non-environmental elements, which, together or individually, became the object of tourist interest (Lijewski, Mikułowski, Wyrzykowski 2002, Kurek 2007). Main elements shaping the touristic value of the region (the game board) are the city's architecture and topography, cultural and religious buildings and artifacts, various ethnic districts, festivals, sport and cultural happenings, the city vibe, academic and artistic potential, the hotel base standard, the variety of restaurants, shopping centres, entertainment centres and sport centres, nightlife, etc.

Cracow is one of the most significant tourist centres in the country not only due to its rich historical and cultural heritage, but also to its wide range of tourist attractions on offer. In the vast city area one can find places suitable to play passionate, commercial and educational kinds of city games. There are 1160 monuments in Cracow listed on the Polish National Monument Record (per December 2011 data), amongst which there are 7 cityscapes, 71 churches and monasteries networks, 7 synagogues, 4 cemeteries, a vast selection of ancient buildings, fortifications, mounts, parks and gardens. The total number of artifacts is estimated for hundreds of thousands. Moreover, Cracow contains in parts of Zespoł Jurajskich Parków Krajobrazowych (ZPKWM), within which there are 5 National Parks, 192 natural monuments, and two ecological districts. Additionally, within Cracow borders there is Bielany-Tyniec, one of the precious Corine biotypes. Furthermore, a part of the city lies in internationally recognized and ecologically significant Vistula river channel. The above mentioned long list of the city attributes can be enriched by its nonmaterial advantages, such as hospitality and the overall Cracow atmosphere, making it perfect location for a city game.

As a form of a tourist attraction, city game combine at least two types of tourist entertainment. It can be seen as a kind of service that is similar to a guided tour or a coherent and organized event evolving around a particular topic, held in a per-determined time and setting, occasionally building up to larger event. The essence of this kind of a produce is to meet the customer needs, which are mainly to relax or actively spend time in the urban area. Naturally, tourist guides leading their groups through usual city paths, brochures and folders get replaced with unmarked routes to be uncovered by the participants solving riddles prompted by maps, pictures, etc. In this way, all players actively participate in the per-designed adventure, but at the same time they can be creative in resolving tasks, uncover mysteries associated with certain places, and finish the game their own way. To lead the game only few people are required, either to set it up beforehand or to support along the way.

Main tasks to be covered when organizing a city game are to ensure health and safety measures and to specify the game mechanics. Among the rules, there are factors determining the victory (reaching the finish in a good time or solving a riddle in a particular time limit), indication of which means of transport can be used, allowing or forbidding the group to split. Some of the examples of a game variations are using passwords and secret codes, the invisible ink, providing frozen prompts, utilizing elements of the signed language, archives, the city's blueprints, clues hidden in books, contact mailboxes, crosswords, or directions written in a foreign language. Very often, city games are introduced by some other kind of an activity, such as an Internet game. Also, it is important to be able to write a city game script so that even with mobile phones and the Internet easily accessible tasks and riddles provided remain demanding. 
O. Nowakowska (2011) has made an attempt to classify city games and distinguished passionate, commercial and educational. Passionate city games are the ones privately initiated either by one person or a group of people that are driven by interest only. Players very frequently form game societies, both in virtual and real worlds.

Educational games are designed by specialists and adopted as part of curriculum on different school levels. Their function in much wider, especially in the light of the currently ongoing debate on the shape and form of secondary and high school final exams (Surdyk 2008). Noticeable is skepticism and even criticism towards incorporating educational elements into everyday teaching. This is not supported by any reason and might only be the result of lack of teacher's knowledge or prejudice against alternative ways of teaching. Main arguments provided by the teaching environment against educational games are low teaching outcome, increase in discipline problems, infantile style and character. Despite the fact that city game is a powerful tool in regional education, it is commonly underestimated. Instead, teachers are traditionally focused on after school clubs, school trips and camps, knowledge competitions (Grelewski, Radojičić 2010).

The commercial type of city games are typically organized by tourist industry offices, event agencies, public relations organizations or tourist agencies. The main focus is on the financial gain. This kind of games is played during sightseeing tours, company away days and workshops and they are frequently designed to perfectly suit the particular occasion and purpose. However, commercial games can also be directed at individual customers wanting to celebrate an occasion or a stag night in a unique way. Companies offering the former type of entertainment are mainly basing their activities on team building principles, aiming at enhancing team's organization and cooperation. They promote their services promising multiple benefits for the employer such as building a great team, integration between employees and the management, familiarizing employees with the brand as well as the company's code of ethics. Commercial city games can be seen as business tourism or a type of motivational tourism, due to their lack of rules and guidelines.

Surveys carried out among young people in Poland (including students of geography and tourism) indicate that city games can become a valuable alternative to traditional guided city tours ( $97 \%$ of the respondents). When having to choose between a tour guide and a city game, a quarter of the respondents would definitely participate in the latter and over a half would probably choose it as preferred form of sightseeing. To justify their choices, a vast number of interviewees suggested that it is an interesting way to see the city, offers entertainment and physical activity, helps remember facts and figures easily, makes sightseeing independent of the tourist guide preferences and schedule, lets visitors to be active and walk off the beaten track. Young tourists is the target group for city games most frequently indicated by the respondents. As the information source for this kind of activities, other people and the Internet were provided.

To sum up, city games, as well as other forms of outdoor activities like questing, can be considered as innovative ways to present, make available, and interpret he natural and cultural heritage. A well prepared city game meets the new tourism trend oscillating around entertainment, emotion, education and engagement $(4 \mathrm{x}$ e). Such organized events are currently developing in Cracow to become more client oriented and entertainment focused. Their number is also increasing. 


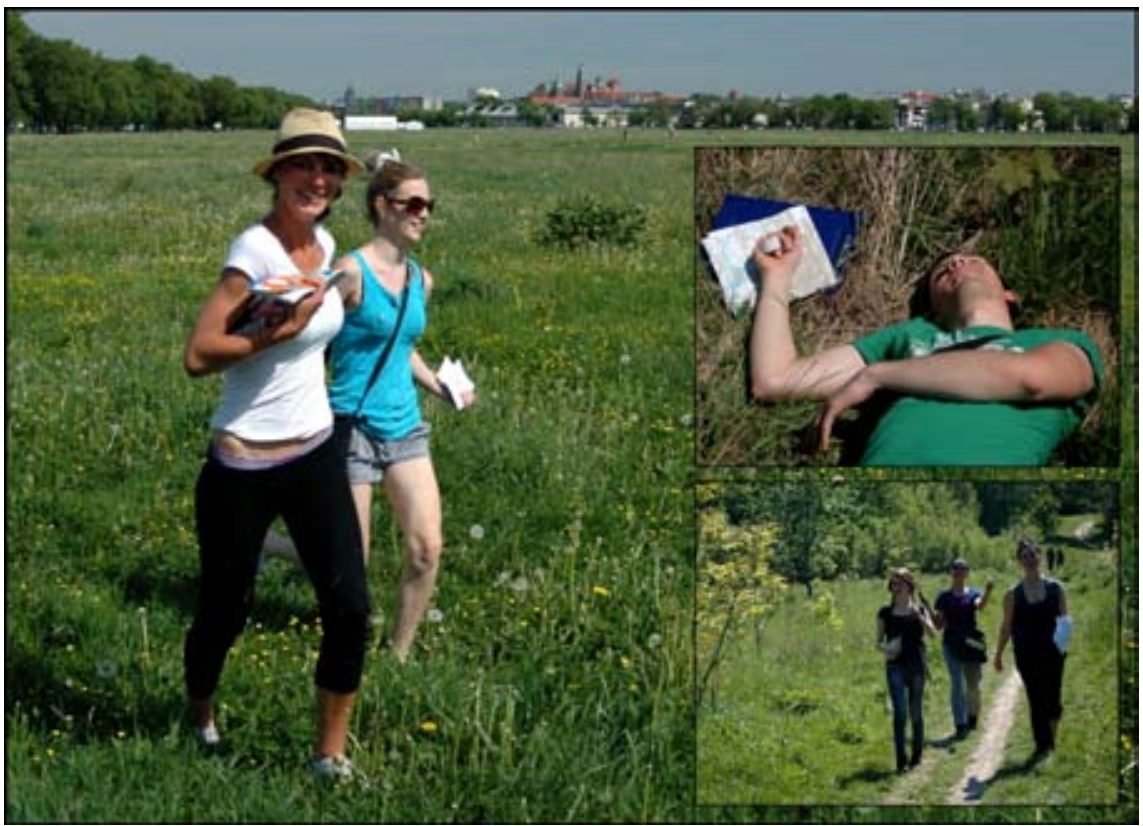

1. Players in the Geoinfotropy game (design by W.Warcholik, fot. W.Warcholik)

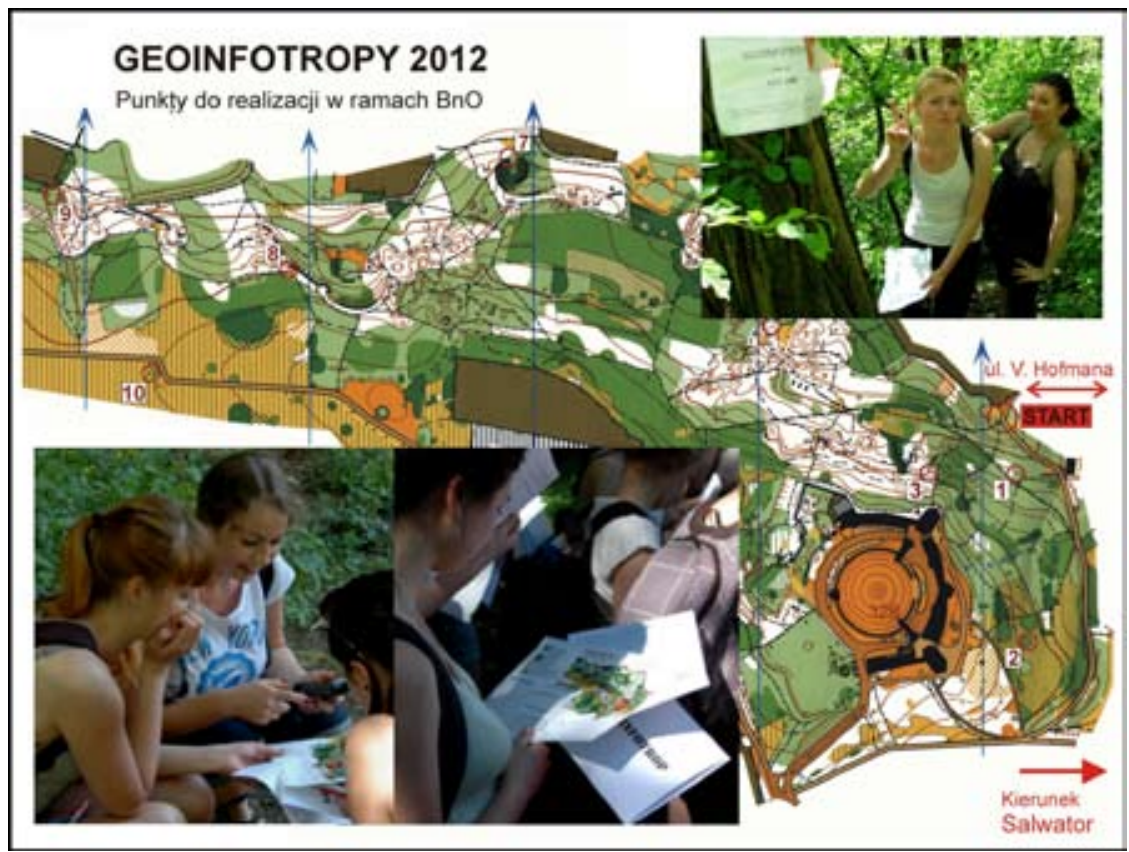

2. Cracow, the location based city game board (Geoinfotropy - design by W.Warcholik, fot. W.Warcholik) 
Furthermore, a city game is such a universal and interdisciplinary tool, that it can be used by teachers, museum keepers, but also by non government organizations and local authorities in their campaign towards promoting the region. Additionally, it can be organized as a commercial type of activity by tourist agencies, public relation offices, event companies, and other tourist industries.

Moreover, city games are a great stimulant; they encourage participants to explore and find their way in alien areas. Their interesting scenarios break the everyday routine and enable players of all ages and abilities to participate and uncover the city. Also, each event of this kind is a game and as such enforces rules and discipline. Finally, city games carry educational value, they develop social skills, teach how to respect principles and values, show how to cooperate.

\section{LIST OF REFERENCES}

1. Ashworth G.J., 2000, The Tourist-historic city. Retrospect and prospect of managing the heritage city, Pergamon/Elsvier, London.

2. Ashworth G. J., 2009, Do Tourists Destroy the Heritage They Have Come to Experience?, Tourism Recreation Research, 34(1), s. 79-83.

3. Corkery C. K., Bailey A. J., 1994, Lobster is big in Boston: postcards, place commodification, and tourism, GeoJournal, 34, 4.

4. Grelewski, Radojičić, 2010, Gry miejskie, jako narzędzie edukacji regionalnej na przykładzie gry ŁódźBój, Geografia w szkole, nr 4, Warszawa.

5. Hughes H., 2003, Arts, entertainment and tourism, Butterworth-Heinemann, OxfordBurlington Impact of Atlanta's hospitality industry. Davidson-Peterson Associates, Atlanta.

6. Kurek W. 2007, Turystyka, Wyd. Nauk PWN, Warszawa, ss. 413.

7. Lew A., 1991, Place representation in tourist guidebooks: an example from Singapore. Singapore Journal of Tropical Geography, 12, 2.

8. Lijewski T., Mikutowski B., Wyrzykowski J., 2001, Geografia turystyki Polski, Polskie Wydawnictwo Ekonomiczne, Warszawa, ss. 378.

9. Nowakowska O., 2011, Wszystko gra! Gry miejskie w przestrzeni Warszawy, Homo Ludens, nr 1 (3), Warszawa.

10. Spack A., 1975, Aspects et problemes touristiques en milieux urbains et périurbains: l'exemple de la ville de Metz et du pays messin. Mosella, 4, 1/2.

11. Surdyk A., 2008, Edukacyjna funkcja gier w dobie „Cywilizacji zabawy”, Homo Communicativus, nr 3(5), Poznań.

12. Wall G., Sinnott J., 1980, Urban recreational and cultural facilities as tourist attractions. The Canadian Geographer, 24, 1.

13. Więckowski R., 1979, Elementy systemu nauczania początkowego, WSiP, Warszawa.

Стаття: надійшла до редколегї 25.05.2012 прийнята до друку 06.06.2012 


\title{
МІСЬКІ ІГРИ В КРАКОВІ ЯК ІННОВАЦІЇ В ТУРИЗМІ?
}

\author{
В. Вархолік \\ Педагогічний Університет в Кракові, інститут географії \\ Заклад туристики та регіональних досліджень
}

Міста завжди були найбільш популярними туристичними дестинаціями. Туризм більше асоціюється з містами, ніж з іншими територіями, а також більше пов'язаний з антропогенними елементами, ніж з природніми ресурсами. Краків, 3-поміж інших, $є$ прикладом міста, де в межах адміністративної території, $є$ багато місць, які не $є$ типово урбанізованими.

Ключові слова: міська гра, туризм, гід, екскурсії по місту.

\section{ГОРОДСКИЕ ИГРЫ В КРАКОВЕ КАК ИННОВАЦИИ В ТУРИЗМЕ?}

\section{В. Вархолик}

\section{Педагогический Университет в Кракове, институт географи} Заведение туристики и региональных исследований

Города всегда были самыми популярными туристическими дестинации. Туризм больше ассоциируется с городами, чем с другими территориями, а также более связан с антропогенными элементами, чем с естественными ресурсами. Краков, из других, является примером города, где в пределах административной территории, есть много мест, которые не типично урбанизированными.

Ключевые слова: городская игра, туризм, гид, экскурсии по городу. 